\title{
Peningkatan Hasil Belajar Matematika Siswa Melalui Pembelajaran Berbantuan GeoGebra di Kelas XII IPA 9 SMA Negeri 1 Palembang
}

\author{
Ayu Mentari ${ }^{*}$, Yanna Sanova ${ }^{2}$ \\ ${ }^{1}$ Universitas Sriwijaya, Palembang, Sumatera Selatan 30139, Indonesia \\ ${ }^{2}$ SMA Negeri 1 Palembang, Palembang, Sumatera Selatan 30139, Indonesia \\ Pengiriman: 19 November 2018; Diterima: 23 April 2019; Publikasi: 30 April 2019 \\ DOI: https://doi.org/10.31629/jg.v4i1.821
}

\begin{abstract}
Abstrak
Penelitian tindakan kelas ini bertujuan untuk meningkatkan hasil belajar matematika siswa kelas XII IPA 9 SMA Negeri 1 Palembang melalui pembelajaran berbantuan GeoGebra. Subjek dalam penelitian ini terdiri dari 29 orang siswa. Materi yang diajarkan dalam penelitian ini adalah nilai maksimum dan minimum, selang kemonotonan, gradien garis singgung, dan selang kecekungan kurva fungsi trigonometri. Siklus pertama dilaksanakan sebanyak tiga pertemuan dan siklus ke-2 sebanyak dua pertemuan. Instrumen yang digunakan adalah tes hasil belajar dan observasi. Tes hasil belajar digunakan untuk mengetahui capaian siswa pada setiap siklus dan observasi digunakan untuk mengumpulkan data selama proses pembelajaran berlangsung. Data dianalisis secara kuantitatif dan deskriptif. Hasil penelitian menunjukkan bahwa nilai rata-rata siswa kelas XII IPA 9 pada tes siklus pertama adalah 50,00 dan pada tes siklus ke-2 sebesar 82,76. Hasil penelitian menunjukkan bahwa pembelajaran berbantuan GeoGebra dapat meningkatkan hasil belajar matematika siswa, yaitu sebesar $80 \%$ siswa telah mencapai ketuntasan pada siklus kedua.
\end{abstract}

Kata kunci: geogebra; hasil belajar; matematika

\begin{abstract}
The aim of this classroom action research is to improve mathematics learning outcomes of students in XII Science 9 Senior High School Number 1 through GeoGebra assisted learning. Subject of this research are 29 students. The lesson taught in this study are maximum and minimum value, monotonicity, slope, and concavity of trigonometric function. First cycle was held in 3 meetings and the second cycle held in 2 meetings. Instrument used is a test of learning outcomes and observation. Learning outcomes test is used to find out student's achievement in each cycle and observation used to collect data during learning process. The data are analized quantitatively and descriptively. Results of the study indicate that the average score of XII Science 9 in the first cycle is 50,00 and in the second cycle is 82,76 . The result of this study show that GeoGebra assisted learning can improve mathematics learning outcomes which is equal to $80 \%$ students have achieved completeness in second cycle.
\end{abstract}

Keywords: geogebra; learning outcomes; mathematics 


\section{JURNAL GANTANG. April 2019; IV(1): 1 - 6 \\ p-ISSN. 2503-0671 \\ e-ISSN. 2548-5547}

\section{Pendahuluan}

Keberhasilan suatu pembelajaran dapat dilihat dari hasil belajar siswa, apakah terjadi perubahan selama proses pembelajaran atau tidak. Penilaian hasil belajar oleh pendidik bertujuan untuk memantau dan mengevaluasi proses, kemajuan belajar, dan perbaikan hasil belajar siswa secara berkesinambungan (Depdiknas, 2016). Terdapat beberapa faktor yang memengaruhi hasil belajar siswa, seperti aktivitas siswa dan persiapan guru dalam mengajar. Kesiapan guru dalam mempersiapkan pembelajaran juga turut mempengaruhi aktivitas apa yang akan dilakukan oleh siswa. Idealnya, kegiatan pembelajaran yang aktif dapat membuat siswa belajar lebih banyak dan melatih siswa untuk mengonstruksi pengetahuannya sendiri.

Fakta yang terjadi di lapangan menunjukkan bahwa hasil belajar matematika siswa masih terkategori rendah. Hal ini dapat ditinjau berdasarkan hasil Ulangan Harian Bersama yang menunjukkan bahwa lebih dari 50\% siswa di kelas XII IPA 9 belum mencapai nilai di atas KKM. Selanjutnya, setelah ditelusuri dari aktivitas pembelajaran sebelumnya, peneliti mengetahui bahwa siswa kesulitan memahami konsep limit dan turunan fungsi trigonometri. Ketika menyelesaikan soal yang diberikan, siswa cenderung mengerjakannya secara prosedural saja tanpa memahami makna limit atau turunan itu sendiri. Peneliti menduga, hal ini terjadi karena dalam proses pembelajaran guru tidak menampilkan konsep limit maupun turunan secara visual kepada siswa. Namun, hasil wawancara dengan guru mengungkapkan bahwa dalam menerangkan konsep limit dan turunan guru sudah membimbing pemahaman siswa menggunakan gambar secara manual di papan tulis.

Berdasarkan hasil refleksi tersebut, peneliti dan guru memutuskan untuk memperbaiki pembelajaran dari aspek media. Hal ini dikarenakan media yang digunakan guru sebelumnya belum cukup efektif meningkatkan pemahaman siswa terhadap konsep limit dan turunan sehingga perlu dilakukan perbaikan terhadap media pembelajaran yang digunakan. Selain itu, pada materi selanjutnya masih berhubungan dengan bentuk-bentuk grafik fungsi trigonometri sehingga peran media dalam membantu proses pembelajaran sangat dibutuhkan. Seperti yang diungkapkan oleh Azhar (2011) bahwa media pembelajaran dapat memberikan pengaruh yang besar terhadap iklim, kondisi, dan lingkungan belajar. Penggunaan media pembelajaran dapat meningkatkan minat belajar siswa dan merangsang siswa untuk aktif mengikuti pembelajaran.

Salah satu upaya yang dapat dilakukan untuk membantu siswa meningkatkan hasil belajar matematikanya adalah dengan menggunakan media pembelajaran yang tepat. Pada pokok bahasan titik-titik stasioner, guru perlu menggunakan media yang dapat memberikan visualisasi dengan baik. Salah satu media yang dapat digunakan, yaitu software GeoGebra. Menurut Hohenwarter, Hohenwarter, Kreis, \& Lavicza (2008) visualisasi yang dinamis dari GeoGebra dapat mendukung percobaan dalam matematika, menghubungkan representasi simbolik dan grafis, serta memberikan dugaan terhadap konsep dasar. Hal senada diungkapkan pula oleh Syahbana (2016), sebagai software yang dinamis GeoGebra dapat digunakan sebagai alat bantu untuk mengonstruksi konsep - konsep matematika. Oleh karena itu, dapat disimpulkan bahwa GeoGebra merupakan media yang cocok digunakan untuk membantu siswa memahami pokok bahasan titik stasioner, yang meliputi nilai maksimum dan minimum, selang kemonotonan, gradien garis singgung, dan selang kecekungan kurva fungsi trigonometri.

Penggunaan GeoGebra untuk meningkatkan hasil belajar matematika siswa telah dibuktikan oleh beberapa penelitian. Hal ini seperti yang dipaparkan oleh Proklamanto \& Rudhito (2013) bahwa program GeoGebra terbukti efektif membantu pemahaman siswa pada materi turunan. Cahyono (2014) juga mengungkapkan bahwa pembelajaran 
menggunakan GeoGebra lebih efektif meningkatkan keaktifan dan hasil belajar siswa. Hal serupa diungkapkan pula pada penelitian Akhirni \& Mahmudi (2015) bahwa pemanfaatan GeoGebra berpengaruh baik terhadap hasil belajar dan motivasi belajar siswa. Selanjutnya, PTK oleh Putro (2016) juga berhasil meningkatkan hasil belajar matematika siswa menggunaka GeoGebra yang dikombinasikan dengan pembelajaran saintifik.

Berdasarkan latar belakang yang peneliti paparkan maka tujuan penelitian ini adalah untuk meningkatkan hasil belajar matematika siswa Kelas XII IPA 9 melalui pembelajaran berbantuan GeoGebra.

\section{Metode Penelitian}

Jenis penelitian yang dilakukan adalah Penelitian tindakan kelas (PTK). Penelitian dilaksanakan secara kolaboratif bersama guru pamong di SMA Negeri 1 Palembang. Subjek dalam penelitian ini adalah siswa Kelas XII IPA 9 SMA Negeri 1 Palembang tahun ajaran 20182019, terdiri dari 29 orang. Adapun kompetensi dasar yang digunakan dalam penelitian ini adalah menjelaskan keterkaitan turunan pertama dan kedua fungsi dengan nilai maksimum, nilai minimum, selang kemonotonan fungsi, kemiringan garis singgung serta titik belok dan selang kecekungan kurva fungsi trigonometri.

Penelitian terdiri dari dua siklus, yaitu siklus pertama sebanyak tiga pertemuan dan siklus kedua sebanyak dua pertemuan. Dalam setiap siklus terdiri dari empat tahap kegiatan, yaitu menyusun rancangan tindakan (planning), pelaksanaan tindakan (acting), pengamatan (observing), dan refleksi (reflecting).

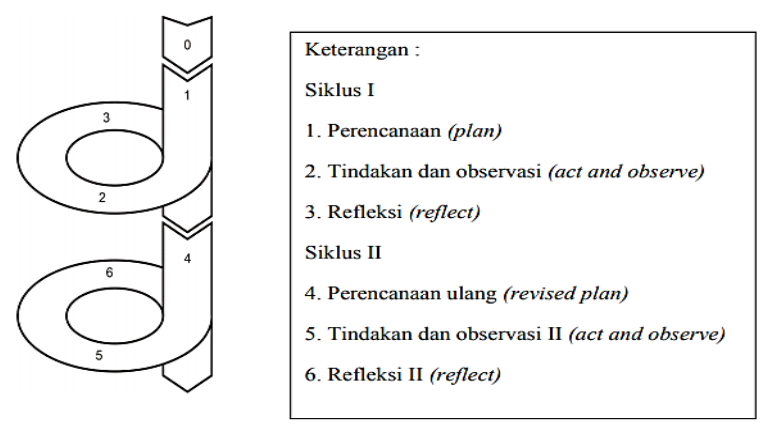

Gambar 1. Desain penelitian
Selanjutnya akan dijelaskan mengenai empat tahapan yang terdapat dalam setiap siklus. Tahap pertama, yaitu perencanaan. Perencanaan adalah kegiatan mengembangkan tindakan yang akan dilakukan pada saat penelitian. Tahap perencanaan dalam penelitian ini, yaitu menentukan kompetensi dasar, membuat Rencana Pelaksanaan Pembelajaran (RPP), membuat bahan ajar, mengembangkan butir soal, menyiapkan media pembelajaran seperti software GeoGebra dan Lembar Kerja Siswa (LKPD), membuat format penilaian, dan mengadakan diskusi dengan beberapa guru matematika yang berperan sebagai rekan sejawat dalam penelitian tentang peningkatan hasil belajar matematika siswa melalui pembelajaran berbantuan GeoGebra dan sebagai pengamat saat proses pembelajaran berlangsung.

Pada tahap pelaksanaan, pembelajaran dilakukan sesuai dengan perencanaan. Tindakan yang dilakukan adalah menerapkan pembelajaran menggunakan GeoGebra pada materi titik-titik stasioner. Materi yang dipelajari pada siklus pertama adalah menentukan nilai maksimum minimum dan selang kemonotonan fungsi trigonometri. Adapun materi pada siklus kedua adalah gradien garis singgung dan kecekungan kurva fungsi trigonometri.

Tahap ketiga, yaitu pengamatan. Penelitian akan dibantu oleh dua orang rekan guru matematika. Rekan guru matematika akan bertindak sebagai observer dalam proses pembelajaran. Kegiatan observasi akan fokus pada pelaksanaan pembelajaran menggunakan GeoGebra sebagai alat bantu pada proses pembelajaran mengenai nilai maksimum minimum, selang kemonotonan, gradien garis singgung, dan kecekungan kurva fungsi trigonometri. Posisi observer berpindah-pindah untuk mengamati aktivitas seluruh siswa dan guru saat berlangsungnya kegiatan pembelajaran.

Tahap terakhir adalah refleksi. Refleksi dilakukan berdasarkan proses pembelajaran yang telah dilaksanakan. Selain itu, hasil observasi yang telah dilakukan selama proses penelitian juga dievaluasi. Selanjutnya, peneliti dan 


\section{JURNAL GANTANG. April 2019; IV(1): 1 - 6 \\ p-ISSN. 2503-0671 \\ e-ISSN. 2548-5547}

observer melakukan pembahasan hasil penilaian yang dilakukan berdasarkan standar keberhasilan yang telah ditetapkan.

Kegiatan yang dilakukan pada siklus kedua merupakan perbaikan dari kegiatan yang telah dilaksanakan pada siklus pertama. Adapun tahapan siklus kedua yang dilalui sama seperti pada siklus pertama, yaitu perencaaan tindakan, pelaksanaan tindakan, pengamatan, dan refleksi. Jika belum terjadi peningkatan, maka siklus dapat dilanjutkan. Pada penelitian ini instrumen yang digunakan adalah Rencana Pelaksanaan Pembalajaran (RPP), bahan ajar, Lembar Kerja Peserta Didik (LKPD), butir-butir soal evaluasi, format penilaian, dan lembar observasi.

Selanjutnya, indikator keberhasilan yang digunakan pada penelitian adalah apabila telah mencapai persentase minimal $75 \%$ dari seluruh siswa yang memperoleh nilai minimal 70 . Nilainilai ini diperoleh berdasarkan hasil penyelesaian butir-butir soal evaluasi. Selain itu, hasil observasi dijadikan sebagai dasar untuk mengamati indikator keberhasilan pada penelitian ini.

\section{Hasil dan Pembahasan}

Penelitian Tindakan Kelas telah dilaksanakan di SMA Negeri 1 Palembang dengan menerapkan pembelajaran berbantuan GeoGebra pada mata pelajaran matematika peminatan. Subjek dalam penelitian ini adalah seluruh siswa kelas XII IPA 9 SMA Negeri 1 Palembang tahun ajaran 2018-2019, yaitu sebanyak 29 orang. Pengambilan data tindakan dilakukan pada 3 Oktober 2018 - 1 November 2018. Penelitian ini dilaksanakan sebanyak dua siklus, tiga pertemuan untuk siklus pertama dan dua pertemuan untuk siklus kedua. Materi yang dipelajari pada siklus pertama, yaitu menentukan nilai maksimum dan nilai minimum, serta menentukan selang kemonotonan fungsi trigonometri. Siklus kedua mempelajari gradien garis singgung dan menentukan selang kecekungan kurva fungsi trigonometri.

Pembelajaran berbantuan GeoGebra dilaksanakan pada setiap pertemuan. Pada setiap kegiatan pembelajaran dilakukan observasi untuk mengetahui aktivitas siswa dalam menyerap materi yang disampaikan oleh guru. Evaluasi diadakan setelah terlaksananya pembelajaran siklus pertama. Berdasarkan hasil evaluasi pada siklus pertama, dilakukan perbaikan rencana pembelajaran yang diterapkan pada siklus kedua. Setelah siklus kedua terlaksana, diadakan evaluasi untuk mengetahui peningkatan hasil belajar siswa.

Ulangan Harian I

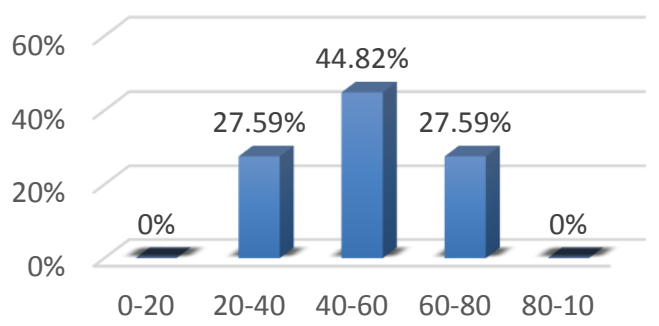

Gambar 2. Hasil ulangan siklus pertama

Berdasarkan diagram pada Gambar 2, dapat dilihat bahwa hanya sebanyak 27,59\% siswa yang mampu mencapai nilai pada kategori tinggi atau rentang nilai $60-80$. Selain itu, ratarata nilai ulangan pada siklus pertama di kelas XII IPA 9 adalah 50,00. Nilai ini masih tergolong di bawah KKM mata pelajaran matematika peminatan.

Selanjutnya, catatan hasil observasi selama pembelajaran siklus pertama, didapat bahwa:

1. Secara umum siswa masih kesulitan untuk mengonstruksi pengetahuan atau ide-ide yang dimiliki untuk menyelesaikan permasalahan yang diberikan, seperti mengaitkan grafik yang tergambar di GeoGebra dengan fungsi turunannya secara aljabar.

2. Setiap kelompok membutuhkan bimbingan atau scaffolding yang cukup banyak untuk mengarahkan siswa pada suatu kesimpulan di dalam LKPD.

3. Pada saat merangkum atau menyimpulkan materi pembelajaran, siswa masih mengalami beberapa kekeliruan meskipun sudah berulang kali diberi arahan oleh guru. 
Berdasarkan data hasil ulangan dan observasi selama pembelajaran, disimpulkan bahwa hasil belajar matematika siswa pada siklus pertama belum mencapai kriteria ketuntasan penelitian. Hal ini menyebabkan perlu dilakukan refleksi dan evaluasi terhadap pembelajaran yang sudah berlangsung. Peneliti bersama dengan guru pamong memperbaiki rencana pembelajaran untuk siklus kedua supaya lebih mudah dipahami oleh siswa. Langkah-langkah penyelesaian dalam LKPD dibuat lebih detail sehingga dapat memberi arahan yang lebih jelas tanpa harus dihampiri oleh guru ke dalam kelompok satu persatu.

Setelah dilaksanakan pembelajaran selama dua pertemuan pada siklus kedua, dilaksanakan ulangan harian 2. Hasil belajar siswa diukur dengan soal ulangan yang berbentuk objektif dan essai. Berikut ini adalah persentase capaian hasil belajar siswa pada siklus kedua. Setelah dilaksanakan pembelajaran selama tiga pertemuan pada siklus pertama, dilaksanakan ulangan harian 1. Hasil belajar siswa diukur dengan soal ulangan yang berbentuk objektif dan essai. Berikut ini adalah persentase capaian hasil belajar siswa pada siklus pertama.

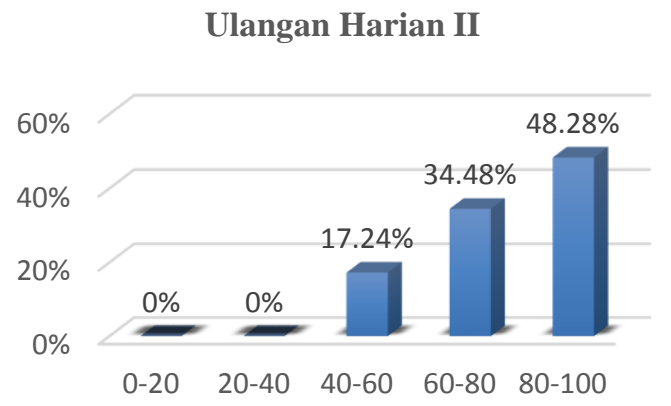

Gambar 3. Hasil ulangan siklus kedua

Berdasarkan diagram pada Gambar 3, dapat dilihat bahwa ada sebanyak 34,48\% siswa yang mampu mencapai nilai pada kategori tinggi atau rentang nilai 60 - 80 dan $48,28 \%$ siswa mencapai nilai pada kategori sangat tinggi atau rentang nilai $80-100$. Apabila dijumlahkan, persentae tersebut sudah lebih dari $75 \%$. Selain itu, rata-rata nilai ulangan pada siklus kedua di kelas XII IPA 9 adalah 82,76. Nilai ini sudah berada di atas KKM mata pelajaran matematika peminatan.

Selanjutnya, catatan hasil observasi selama pembelajaran siklus kedua, didapat bahwa:

1. Siswa mulai terbiasa untuk mengikuti langkah penyelesaian di dalam LKPD secara mandiri, seperti ketika menghubungkan nilai gradien atau turunan pertama dan kedua pada selang tertentu grafik fungsi trigonometri.

2. Bimbingan atau scaffolding yang diberikan guru mulai berkurang, ini menunjukkan kemandirian siswa dan kerja sama di dalam kelompok sudah semakin baik.

3. Pada saat kegiatan merangkum dan menyimpulkan hasil belajar, siswa antusias untuk mengungkapkan hasil diskusi kelompoknya dengan benar sehingga guru tidak terlalu banyak memberi koreksi.

Berdasarkan data hasil ulangan harian 2 dan observasi selama pembelajaran, disimpulkan bahwa hasil belajar matematika siswa pada siklus kedua telah memenuhi kriteria ketuntasan penelitian. Hal ini menyebabkan tidak perlu dilaksanakan siklus selanjutnya atau dengan kata lain penelitian tindakan kelas ini selesai.

Hasil ulangan harian dan data hasil observasi pada setiap siklus menunjukkan bahwa hasil belajar matematika siswa kelas XII IPA 9 mengalami peningkatan. Hal ini disebabkan oleh pembelajaran berbantuan GeoGebra yang dilaksanakan secara berkelompok atau kooperatif mampu menggiring siswa untuk berpikir kritis dan mengonstruksi pengetahuannya sendiri. Penggunaan GeoGebra sebagai aplikasi yang membantu proses pembelajaran juga menarik minat dan motivasi siswa dalam belajar. Visualisasi dinamis yang bisa ditampilkan oleh GeoGebra membantu siswa untuk memahami pelajaran dengan lebih mudah. Hal ini menunjukkan bahwa apa yang terjadi dalam PTK ini sejalan dengan penelitian terdahulu oleh Proklamanto \& Rudhito (2013), 


\section{JURNAL GANTANG. April 2019; IV(1): 1 - 6 \\ p-ISSN. 2503-0671 \\ e-ISSN. 2548-5547}

Cahyono (2014), Akhirni \& Mahmudi (2015), dan Putro (2016) bahwa penggunaan GeoGebra efektif dalam meningkatkan hasil belajar matematika siswa.

\section{Kesimpulan}

Berdasarkan data hasil PTK yang telah dilaksanakan dalam dua siklus, dapat disimpulkan bahwa pembelajaran dengan berbantuan GeoGebra dapat meningkatkan hasil belajar siswa Kelas XII IPA 9 SMA Negeri 1 Palembang. Hal ini terbukti dengan adanya peningkatan nilai ulangan harian dari siklus pertama dengan nilai rata-rata 50,00 menjadi 82,76 pada siklus kedua. Kemudian untuk persentase capaian hasil belajar menunjukkan pada siklus kedua sebanyak $82,67 \%$ siswa telah mendapat nilai pada kategori tinggi dan sangat tinggi. Selanjutnya, berdasarkan hasil observasi pada siklus pertama dan kedua juga menunjukkan siswa mengalami perubahan cara belajar yang lebih baik dengan bantuan GeoGebra sehingga berpengaruh pada hasil belajar matematikanya.

\section{Ucapan Terimakasih}

Artikel ini merupakan publikasi hasil penelitian kolaborasi mahasiswa PPG Prajabatan Bersubsidi Universitas Sriwijaya selama melaksanakan PPL di SMA Negeri 1 Palembang. Oleh karena itu, penulis mengucapkan terima kasih kepada Kemristekdikti, Universitas Sriwijaya, dan SMA Negeri 1 Palembang yang telah mendukung pelaksanaan penelitian ini.

\section{Referensi}

Akhirni, A., \& Mahmudi, A. (2015). Pengaruh pemanfaatan cabri 3D dan geogebra pada pembelajaran geometri ditinjau dari hasil belajar dan motivasi. Jurnal Pendidikan Dan Sains, 3(2), 91-100.

Azhar, A. (2011). Media pembelajaran. Jakarta: PT Raja Grafindo Persada

Cahyono, B. (2014). Implementasi media software geogebra dan screencase dalam pembelajaran geometri transformasi untuk meningkatkan hasil belajar mahasiswa tadris matematika. AKSIOMA: Jurnal Matematika Dan Pendidikan Matematika, 5(2), 24-37.

Depdiknas. (2016). Permendikbud No.23 tahun 2016.https://doi.org/http://dx.doi.org/10.10 16/j.athoracsur.2009.09.030

Hohenwarter, M., Hohenwarter, J., Kreis, Y., \& Lavicza, Z. (2008). Teaching and learning calculus with free dynamic mathematics software geogebra. Research and Development in the Teaching and Learning of Calculus, TSG 16(September 2016), 1-9.

Proklamanto, A. R., \& Rudhito, M. A. (2013). Efektifitas pemanfaatan program geogebra pada pembelajaran matematika dalam upaya membantu pemahaman materi turunan. Prosiding Seminar Nasional Sains Dan Pendidikan Sains VIII Fakultas Sains Dan Matematika UKSW, 4(1), 217-226.

Putro, K. I. R. S. (2016). Pemanfaatan APBS dan geogebra untuk meningkatkan minat dan hasil belajar matematika di SMP. Jurnal Managemen Pendidikan, 11(2), 50-59.

Syahbana, A. (2016). Belajar menguasai geogebra. Palembang: Noer Fikri Offset. 